\title{
In vivo knockdown of GAD67 in the amygdala disrupts fear extinction and the anxiolytic-like effect of diazepam in mice
}

\author{
SA Heldt ${ }^{1,2}$, L Mou ${ }^{3}$ and KJ Ressler ${ }^{3,4}$
}

In mammals, $\gamma$-aminobutyric acid (GABA) transmission in the amygdala is particularly important for controlling levels of fear and anxiety. Most GABA synthesis in the brain is catalyzed in inhibitory neurons from L-glutamic acid by the enzyme glutamic acid decarboxylase 67 (GAD67). In the current study, we sought to examine the acquisition and extinction of conditioned fear in mice with knocked down expression of the GABA synthesizing enzyme GAD67 in the amygdala using a lentiviral-based (LV) RNA interference strategy to locally induce loss-of-function. In vitro experiments revealed that our LV-siRNA-GAD67 construct diminished the expression of GAD67 as determined with western blot and fluorescent immunocytochemical analyses. In vivo experiments, in which male C57BL/6J mice received bilateral amygdala microinjections, revealed that LV-siRNA-GAD67 injections produce significant inhibition of endogenous GAD67 when compared with control injections. In contrast, no significant changes in GAD65 expression were detected in the amygdala, validating the specificity of LV knockdown. Behavioral experiments showed that LV knockdown of GAD67 results in a deficit in the extinction, but not the acquisition or retention, of fear as measured by conditioned freezing. GAD67 knockdown did not affect baseline locomotion or basal measures of anxiety as measured in open field apparatus. However, diminished GAD67 in the amygdala blunted the anxiolytic-like effect of diazepam $\left(1.5 \mathrm{mg} \mathrm{kg}^{-1}\right)$ as measured in the elevated plus maze. Together, these studies suggest that of GABAergic transmission in amygdala mediates the inhibition of conditioned fear and the anxiolytic-like effect of diazepam in adult mice.

Translational Psychiatry (2012) 2, e181; doi:10.1038/tp.2012.101; published online 13 November 2012

\section{Introduction}

Clinical evidence suggests that alterations in normal $\gamma$ aminobutyric acid (GABA) transmission might contribute to the pathophysiology of anxiety disorders in humans. For instance, various studies using nuclear imaging techniques have revealed diminished central GABA and GABA receptor levels in patients suffering from anxiety disorders, including panic disorder, generalized anxiety disorder and posttraumatic stress disorder. ${ }^{1-8}$ Blunted behavioral and central effects to benzodiazepine (BZ) administration have also been reported in patients with panic disorder. ${ }^{9-11}$ Previous work has also revealed that individuals with low GABA plasma levels at the time of trauma are reportedly more prone to develop acute posttraumatic stress disorder than other victims. $^{12,13}$ The link between altered GABAergic transmission and anxiety disorders is also bolstered by the fact that patients suffering from anxiety disorders are commonly treated with $\mathrm{BZs}$, which mediate their actions by augmenting the inhibitory actions of GABA.

Altered GABAergic transmission in the amygdala may be a major factor contributing to the behavioral symptoms associated with anxiety disorders. In mammals, the amygdala is rich in A-type GABA receptors (GABAARs), which are particularly important for controlling fear and anxiety. ${ }^{14-19}$ In rodents, the anxiolytic-like effects of $\mathrm{BZs}$ injected into the amygdala have been demonstrated on a number of animal models of anxiety, including the elevated plus maze (EPM), ${ }^{20-22}$ social interaction tests, ${ }^{23}$ conflict tests, ${ }^{24-26}$ defensive freezing $^{27}$ and conditioned avoidance. ${ }^{28}$ On the other hand, microinjections of BZ antagonists and inverse agonists into the amygdala induce anxiogenic-like behaviors ${ }^{26,29}$ and prevent the anxiolytic-like effects BZs. ${ }^{24,30}$

Behavioral and physiological lines of evidence suggest that GABAergic transmission in the amygdala undergoes plastic changes that contribute to the control of fear and anxiety. For example, tone fear-conditioning results in a significant reduction of extracellular GABA levels in the amygdala during subsequent re-exposure to a tone conditioned stimulus (CS). ${ }^{31}$ Likewise, the expression of the GABA synthesizing enzyme GAD65 is reduced in the amygdala $24 \mathrm{~h}$ after fearconditioning training. ${ }^{32}$ Studies investigating in vitro long-term potentiation in amygdala indicate that both excitatory synapses onto interneurons and inhibitory synapses onto pyramidal cells can undergo long-term potentiation. ${ }^{33,34}$ Both forms of GABAergic long-term potentiation induce lasting potentiation of inhibitory postsynaptic potentials recorded from amygdala pyramidal neurons and may contribute to the modification of amygdala inhibitory networks. Together, these

${ }^{1}$ Department of Anatomy and Neurobiology, University of Tennessee Health Science Center, Memphis, TN, USA; ${ }^{2}$ Neuroscience Institute, University of Tennessee Health Science Center, Memphis, TN, USA; ${ }^{3}$ Department of Psychiatry and Behavioral Sciences, Emory University, Atlanta, GA, USA and ${ }^{4}$ Howard Hughes Medical Institute, Bethesda, MD, USA

Correspondence: Dr SA Heldt, University of Tennessee Health Science Center, 855 Monroe Avenue, Memphis, TN 38163, USA.

E-mail: sheldt@uthsc.edu

Keywords: amygdala; extinction; fear; GABA; GAD67; lentivirus

Received 8 August 2012; accepted 18 August 2012 
studies suggest that inhibitory transmission in the amygdala undergoes experience-dependent changes and that alterations in plastic changes may participate in the development and/or symptoms associated with fear and anxiety.

Although the mechanisms underlying changes in GABAergic neurotransmission are poorly understood, activity-dependent changes in the $67-\mathrm{kDa}$ isoform of glutamic acid decarboxylase (GAD67) may play a particularly important role in the alteration of inhibitory synaptic transmission. GAD67, along with a second isozyme GAD65, regulate GABA synthesis in the brain $^{35}$ and readily influence cellular and vesicular GABA content. ${ }^{36}$ The evidence from knockout mice indicates that GAD67 provides the majority of basal GABA for inhibitory neurotransmission. Deletion of the GAD67 gene in mice results in $>90 \%$ reduction in basal GABA levels in the brain; ${ }^{37,38}$ whereas, GAD65 deleted homozygous mice express normal levels of GABA. ${ }^{39}$ Levels of GAD67 are also known to change in response to functional demands of GABA. For example, activity-dependent increases in GAD67 lead to enhanced GABA synthesis; ${ }^{35,40}$ whereas activity deprivation decreases GABA levels, likely through down-regulation of GAD67. Altogether, these data indicate that changes in basal and activity-dependent levels of GAD67 can readily influence GABAergic neurotransmission and that alterations in GAD67 levels may participate in the development and/or symptoms associated with fear and anxiety.

In the present study, we investigated whether altered amygdala GAD67 modulates levels of fear/anxiety and the behavioral effects of the BZ diazepam in adult mice. Specifically, we performed local intracerebral infusions of a small interfering RNA lentivirus (LV-siRNA), engineered to specifically knockdown GAD67 in the amygdala of adult mice, before behavioral testing. Since GAD67 is the rate-limiting enzyme in controlling GABA synthesis, we hypothesized that the LV-induced reduction of GAD67 would decrease GABAmediated signaling and produce an anxiogenic-like profile in mice as reflected by increased unconditioned and conditioned fear. We also predicted that amygdala GAD67 reduction would blunt the anxiolytic-like effect to the administration of the BZ diazepam.

\section{Materials and methods}

Animals. Male C57BL/6J mice (5 weeks of age) were purchased from Jackson Laboratory and allowed to acclimate in the vivarium for 2-3 weeks before surgery. Mice were housed in standard group cages ( $<6$ per cage) and were given ad libitum access to food and water on a 12-h light/dark cycle (light on from 0700 hours). All experiments were performed during the light cycle. This research followed the principles and standards of animal care outlined by the $\mathrm{NIH}$ Institutional Animal Care and Use Committee ${ }^{41}$ and approved by the UTHSC and Emory University Institutional Review Boards.

Test drug and dose. Diazepam, a nonselective full BZ receptor agonist (Sigma, St Louis, MO, USA) was dissolved in a $15 \% \mathrm{DMSO} /$ saline solution and administered in a volume of $8 \mathrm{ml} \mathrm{kg}^{-1}$ at a dose of $1.5 \mathrm{mg} \mathrm{kg}^{-1}$. Dose selection was based on previous study, demonstrating that this level produces a robust anxiolytic-like behavioral effect when measure using the EPM. ${ }^{42}$ Animal weights were recorded before injections.

Lentivirus production. Viral vectors were derived from the HIV-based lentivirus backbone pLV-CMV-GFP-U3Nhe, which allows for virally mediated expression of green fluorescent protein (GFP) driven by a cytomegalovirus (CMV) promoter. ${ }^{43}$ Each small interfering RNA-expressing viral vector (LV-siRNA) was created by subcloning a $\mathrm{H} 1$ siRNA coding cassette into the Nhe1 restriction enzyme site of the pLV-CMV-GFP-U3Nhe backbone. The H1-siRNA cassette was constructed by first obtaining the 60-64 bp sense and antisense oligonucleotides against GAD67 (siGAD67) (Sigma) containing the target sequence separated from its reverse complement by a 7-bp loop sequence. Scrambledsequence oligonucleotides (SCR) were used to create control construct. The sense and antisense oligonucleotides also contained overhangs of BgIl at the $5^{\prime}$ end and HindIII at the $3^{\prime}$ end downstream of a $\mathrm{H} 1 \mathrm{pol}$ III promoter. After annealing and phosphorylating the antisense oligonucleotides, the duplex was ligated between BgIII and HindIII of the pSuper plasmid. The HI-siRNA cassette from pSuper plasmid was PCR amplified using T3 and SK-Xba primers (T3-5'-CTCGAAATTAACCCTCACTAAAGGG-3'; SK-Xbs-5'-CGAAGGTCGACG GTCTAGATAAGC-3'). The resulting PCR product was digested with $X b a 1$ and subcloned into the pLV-CMV-GFPU3Nhe backbone to create LV-siGAD67 or LV-SCR control lentiviral constructs. Active viral particles were produced by co-transfecting these lentiviral packaging constructs with plasmids coding for delta8.9 and VSV-G into HEK-293 T cells following standard methods. ${ }^{44-46}$ The packaged, unconcentrated virus was collected over a period of 5 days posttransfection, and then concentrated using ultracentrifugation and resuspended in sterile $\mathrm{PBS} / 1 \%$ bovine serum albumin (BSA). The resulting titer was assessed in HEK-293 T cells and ranged from $1 \times 10^{8}$ to $1 \times 10^{9}$ infectious particles per $\mathrm{ml}$.

Motor activity apparatus. Baseline motor activity and the sedative effects of diazepam were measured by examining the total ambulatory distance (in $\mathrm{cm}$ ) during the 30-min open field test session. Activity for each mouse were measured using individual activity chambers $(27.9 \mathrm{~cm} \times 27.9 \mathrm{~cm})$ constructed from clear polycarbonate and equipped with four 16-beam infrared arrays across the base of each chamber wall (MED Associates, St Albans, VT, USA, Model, OFA-MS). The percentage of time mice spent in the central zone of the open field was used as index of anxiety-like behavior. The central zone was defined as the central compartment of the floor located $6 \mathrm{~cm}$ from the perimeter of the chamber walls. Activity data were collected via computer and analyzed with the MED Associates' Activity Monitor Data Analysis software.

EPM apparatus. The EPM consists of two open arms $\left(50 \times 6.5 \mathrm{~cm}^{2}\right)$ and two closed arms with a wall $(50 \times$ $6.5 \times 15 \mathrm{~cm}^{3}$ ) attached to a common central platform $\left(6.5 \times 6.5 \mathrm{~cm}^{2}\right)$ to form a cross. The maze was elevated $65 \mathrm{~cm}$ above the floor. Test sessions were conducted under adjusted room lighting (100lux) where behaviors were continuously videotaped by a video camera placed over the 
apparatus. The total number of closed arm entries was used as an indicator of locomotor activity. ${ }^{47}$ Arm entries and latencies were analyzed and recorded via computer using automated Limelight software (Coulbourn, PA, USA).

Fear-conditioning apparatus. Mice were given fear conditioning in standard rodent modular test chambers (ENV008-VP; MED Associates, St Albans, VT, USA) equipped with high-frequency speakers mounted inside each chamber. The tone CS was a $30-\mathrm{s}, 70-\mathrm{dB}$ SPL, 12-kHz tone delivered by GW Instek function generator (GFG-1003, Instek, Chino, CA, USA). The US (unconditioned stimulus) was scrambled foot shock delivered by current generator (Model ENV-414, MED Associates, St Albans, VT, USA) to a removable grid floor that consisted of 36 stainless steel rods $(3.2 \mathrm{~mm})$ placed $7.9 \mathrm{~mm}$ apart. The footshock US intensity was $0.4 \mathrm{~mA}$ verified by using a $0.5-\mathrm{kOhm}$ resistor across the bars of the shock grids and measuring the voltage drop between the bars to calculate the constant current. Conditioned freezing responses were recorded with video cameras mounted on top of each conditioning apparatus. Footshock stimuli and freezing responses were controlled, collected and analyzed via computer using automated FreezeFrame2 software (Coulbourn, Whitehall, PA, USA).

Cell culture experiments. Primary cultures of hippocampal neurons from C57BL/6J mice (P10) were prepared using a modified protocol based on Brewer. ${ }^{48}$ Briefly, the hippocampi were dissected on ice and dissociated in Hibernate $A$ medium (BrainBits, Springfield, IL, USA). Neurons were plated onto poly-D-lysine-pre-coated 24-well plates at a density of $2.5 \times 10^{5}$ cells $\mathrm{cm}^{-2}$ in Neurobasal A media (Invitrogen, Carlsbad, CA, USA). The cultures were kept in a humidified incubator at $37^{\circ} \mathrm{C}$ and $5 \% \mathrm{CO}_{2}$. Two weeks after plating, each well received either $1 \mu \mathrm{l}$ of LV-siGAD67, LVSCR, or was left untreated followed by 3 days of incubation at $37^{\circ} \mathrm{C}$ and $5 \% \quad \mathrm{CO}_{2}$. Neurons were then fixed with $4 \%$ paraformaldehyde in PBS and blocked from nonspecific binding in PBS containing 1\% BSA and 3\% normal goat serum. GAD67 protein was stained with rabbit anti-GAD67 antibody (MAB5406; 1:500; Millipore, Billerica, MA, USA) and goat anti-rabbit Alexa Fluor 568 (1:1000; Invitrogen). After PBS rinse, cells were treated with Hoechst 33342 stain $\left(10 \mu \mathrm{g} \mathrm{ml}^{-1}\right)$ for $10 \mathrm{~min}$ to identify nuclei of both neuronal and glial cells. Wells were viewed using a Leica DMRA microscope (Nussloch, Germany) and random images from LVSCR, LV-siGAD67, and untreated wells $(n s=8$, area $=0.175$ $\mathrm{cm}^{2}$ per each) were captured using a Nikon Digital Sight DS-U1 camera system and NIS Elements BR2.30 Software. Hoechst, GAD67 and GFP-positive neurons from the same area were counted, and the level of infection was calculated as a percentage of the total Hoechst-stained nuclei.

Surgery and testing. Mice received bilateral microinjections of either the LV-siGAD67 or the control LV-SCR into the lateral and basolateral amygdala (BLA). After anesthetizing by injections of Ketamine-Metomidine $\left(80 \mathrm{mg} \mathrm{kg}^{-1}: 1.0 \mathrm{mg} \mathrm{kg}^{-1}\right.$, i.p.), mice were mounted in a stereotaxic apparatus, and small holes were drilled in the skull above the injection site. A 30-gauge Hamilton microsyringe was lowered to the following coordinates from bregma based on the mouse brain atlas of Paxinos and Franklin: ${ }^{49} \mathrm{AP}=-1.4, \mathrm{ML}= \pm 3.3, \mathrm{DV}=-5.0$. The microsyringe was left in place $10 \mathrm{~min}$ before and after each injection, and a total volume of $1.0 \mu \mathrm{LLV}$-siGAD67 or LVSCR was administered at a rate of $0.05 \mu \mathrm{l}$ per min at each site. The incision was closed with Cyanoacrylate glue after surgery. Each mouse was placed on a heated pad after a postsurgical i.p. injection of Antisedan $\left(4.0 \mathrm{mg} \mathrm{kg}^{-1}\right)$ and the narcotic analgesic buprenorphine $\left(0.05 \mathrm{mg} \mathrm{kg}^{-1}\right.$, s.c.) was administered to mice after recovery from anesthesia. Postsurgical monitoring was performed before testing. Forty-four mice received $L V$ injections (LV-SiGAD67 $=22, \quad L V-S C R=22$ ), three mice died during surgery or recovery period.

Prior testing can alter performance on subsequent tests. ${ }^{50}$ To reduce this impact, the test order of behavioral tests was arranged so that mice were evaluated on a tests viewed to be least invasive before more invasive tests. ${ }^{51}$ Two weeks after surgery, the effect of GAD67 knockdown on motor activity was analyzed. Three days later, LV-siGAD67 and LV-SCR mice ( $n=20$, each group) were tested on the EPM. Half of each surgery group $(\mathrm{ns}=10)$ received $1.5 \mathrm{mg} \mathrm{kg}^{-1}$ per i.p. of diazepam $30 \mathrm{~min}$ before testing. The second half of each group $(n s=10)$ received vehicle. Studies of concentrationtime profiles in adult mice indicate the half-lives of diazepam and metabolites are $\sim 8 \mathrm{~h}$ after a single dose. ${ }^{52,53}$ Thus, to limit the effects of prior diazepam treatment on subsequent testing, fear conditioning was conducted following a 3-day drug washout period after EPM testing. The testing order for animals was counterbalanced for treatment condition, and experimenters were blind to the treatment condition of mice.

Motor and EPM testing. Baseline motor activity was measured by examining the total ambulatory distance (in $\mathrm{cm}$ ) during the 30-min open field test session. For EPM testing, each animal was weighed and injected with diazepam $(1.5 \mathrm{mg}$ $\mathrm{kg}^{-1}$ ) or vehicle (15\% DMSO/saline). At the start of each session, a mouse was placed in the central 'hub' of the maze with its head facing an open arm and was allowed to freely explore for $5 \mathrm{~min}$. The percentage of open arm entries ([open arm/(open + closed arm) entries] $\times 100)$ and percentage time in open arms ([time in open arms/(time in open + closed arms)] $\times 100$ ) were computed. Both of these parameters are indicators of an anxiolytic-like effect. ${ }^{54,55}$ The total number of closed arm entries was used as an indicator of locomotor activity. ${ }^{47}$ Arm entry was considered complete if all four paws entered a closed or open arm from the central platform.

Conditioned fear training, retention and extinction. During training, mice were placed in chambers, and after $5 \mathrm{~min}$, received the first of 5 tone + shock trials at a 2-min variable intertrial interval (range, 1-3 min). One day after training, animals were given a retention test session containing 15 CS-alone test trials (intertrial interval, $2 \mathrm{~min}$ ). The extinction training consisted of six test sessions. On each of six consecutive days, mice were given a test session consisting of $15 \mathrm{CS}$-alone test trials (tone-no shock). CS-alone test trials were presented at an intertrial interval of $2 \mathrm{~min}$.

Behavioral data analyses. Levene's and Bartlett's tests conducted on data sets showed no strong departures from 
normality and homogeneity, respectively. In no cases were both the normality and homogeneity of variance assumptions violated, thus parametric tests were used to analyze data sets.

EPM-dependent measures, including percent of open arm entries and percent of open arms time, were analyzed separately by means of a $2 \times 2$ ANOVA (analysis of variance) with surgery group (LV-siGAD67, LV-SCR and drug level (Nondrug, Drug) as the between-subjects factors. The 30-min open field test session was evaluated with surgery group as a between-subjects factor and blocks of 10-min intervals (blocks 1-3) as a within-subjects factor. The acquisition of conditioned freezing was analyzed by means of a repeated-measure ANOVA with surgery group as a between-subjects factor and training trial (trials 1-5) as a within-subjects factor. The retention of fear was analyzed by comparing group mean freezing responses (session 1) using a $t$-test. The acquisition of extinction was analyzed by means of a repeated-measure ANOVA with surgery group as a between-subjects factor and test session (sessions 1-6) as a within-subjects factor.

Histological analyses. The effectiveness and consequences of LV-siGAD67-induced gene knockdown in the amygdala were assessed by quantifying GAD67 protein levels and mRNA levels of GAD67 and GAD65. Protein levels were assessed by via western immunoblotting and mRNA levels via in situ hybridization.

Western immunoblots. The brains were removed and blocked rapidly over ice into $2 \mathrm{~mm}$-thick coronal sections. Amygdala punches were obtained with a 1-mm brain punch tool, and punches from each side were homogenized on ice with a sonicator in $25 \mu \mathrm{l}$ homogenized lysis buffer (5 mM HEPES, $1 \mu \mathrm{m}$ EDTA, protease inhibitors) with a protease inhibitor cocktail kit (Roche, Indianapolis, IN, USA). These samples were kept frozen at $-80^{\circ} \mathrm{C}$ until western blot assay. Protein concentrations were measured using $2.5 \mu \mathrm{l}$ samples of homogenates with BCA protein assay reagent and $B S A$ as the reference standard (Pierce, Rockford, IL, USA). ${ }^{56}$ After boiling for $5 \mathrm{~min}$, equal amounts of protein $(20 \mu \mathrm{g})$ were subjected to polyacrylamide gel electrophoresis using $7.5 \%$ polyacrylamide gels (Bio-Rad Laboratories, Hercules, CA, USA) to separate proteins. After electrophoresis, samples were transferred to nitrocellulose membrane $(0.45 \mu \mathrm{m}$, Bio-Rad Laboratories) at $30 \mathrm{~mA}$ for $2 \mathrm{~h}$ at $4{ }^{\circ} \mathrm{C}(25 \mathrm{~mm}$ Tris- $\mathrm{HCl}, 190 \mathrm{~mm}$ glycine, $20 \%$ methanol). Membranes were washed three times for $5 \mathrm{~min}$ with blocking buffer ( $2 \%$ nonfat dry milk, $0.1 \%$ Tween 20, $50 \mathrm{~mm} \mathrm{NaCl}, 10 \mathrm{~mm}$ HEPES, $\mathrm{pH}$ 7.4), then incubated with a primary antibody at $4{ }^{\circ} \mathrm{C}$ overnight. Following three 5-min washes with blocking buffer, membranes were incubated with a corresponding HRP-coupled secondary antibody (1:4000 dilution) at room temperature for $60 \mathrm{~min}$, subsequently washed with water to remove the substrate solution, and detected with SuperSignal West chemiluminescence substrate (Pierce). Protein bands were visualized and analyzed using an Alpha Innotech Fluorchem imaging system (Alpha Innotech, San Leandro, CA, USA).
Monoclonal mouse anti-glyceraldehyde-3-phosphate dehydrogenase antibody (GAPDH; 1:3000) was obtained from Fitzgerald Industries (Concord, MA, USA). Total blotted protein levels were normalized to levels of GAPDH to control for variations in protein loading. As such, the relative values were quantified as the protein of interest divided by the loading control. Statistical analyses were performed with independent samples $t$-tests (LSD). For ease of presentation, figures are presented as percentages of control group (LV-SCR).

In situ hybridization. Mice were anesthetized with isoflurane and the brains were rapidly dissected and frozen on crushed dry ice. Coronal sections $(20 \mu \mathrm{m})$ of the brains were cut on a cryostat (Leica) at $-20^{\circ} \mathrm{C}$, mounted on gelatin-coated slides, and stored at $-80^{\circ} \mathrm{C}$ until processed for histochemistry. For each brain, sections were placed on consecutive sets of slides such that each set contained similar sequential sections of the brain. Sections were collected from areas before the amygdala to anterior areas of the pretectal nucleus of the thalamus. One set of slide from each brain was used for in situ hybridization analyses of mRNA. One slide set was stained with Nissl stain.

In situ hybridization and analyses were performed to examine the expression of GAD67 mRNA as previously described and validated. ${ }^{42,57,58}$ Briefly, hybridization riboprobes were prepared from linearized clones using appropriate RNA polymerase and radioactive 35 S-UTP in the polymerase reaction. Radiolabeled antisense RNA strands were base hydrolyzed and isolated using a sephadex spin columns (Roche). Probes were diluted to a concentration of 100000 c.p.m. per $\mu \mathrm{l}$ in buffer, and sections were incubated overnight in humid chambers at $52^{\circ} \mathrm{C}$ with $75 \mu$ l of probebuffer solution covered with a Parafilm coverslip. Slides were then washed, air dried and placed against Biomax MR autoradiography film (Eastman Kodak, New York, NY, USA) for 2 days. Next, film was scanned (3000 dpi) and saved in JPEG format. To estimate the levels of mRNA, the total area of each target site subregion was outlined with reference to Nissl-stained sections and the atlas of Paxinos and Franklin. ${ }^{49}$ Nissl-stained sections were also used for the identification of injection sites.

The hybridization signal intensities of the brain regions were calculated on the basis of gray values between 0 and 255 . Hybridization signals were determined for the regions of interest, as well as an adjacent background area with little or no hybridization signal.

\section{Results}

In vitro efficiency of GAD67 protein knockdown in primary cell cultures. The lentivirus designed to knockdown expression of GAD67 was initially tested in vitro by examining its efficiency in knocking down the expression of GAD67 primary cultures of hippocampal neurons from C57BL/6J mice (P10). For this experiment, 24-well plate cell cultures were treated with either $1 \mu \mathrm{l}$ of LV-siGAD67, $1 \mu \mathrm{l}$ of LV-SCR or left untreated. Three days later, plates were processed for either immunocytochemistry (ICC) or western blotting. In general, ICC images revealed pronounced GFP expression in lentiviral-infected wells. As seen in Figure 1a, 

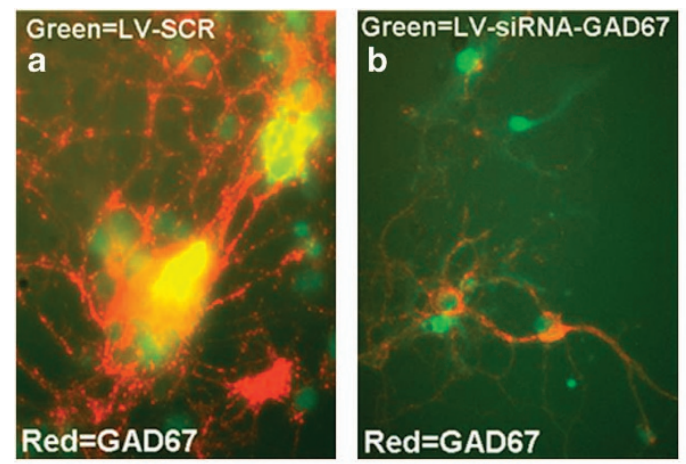

\section{d}
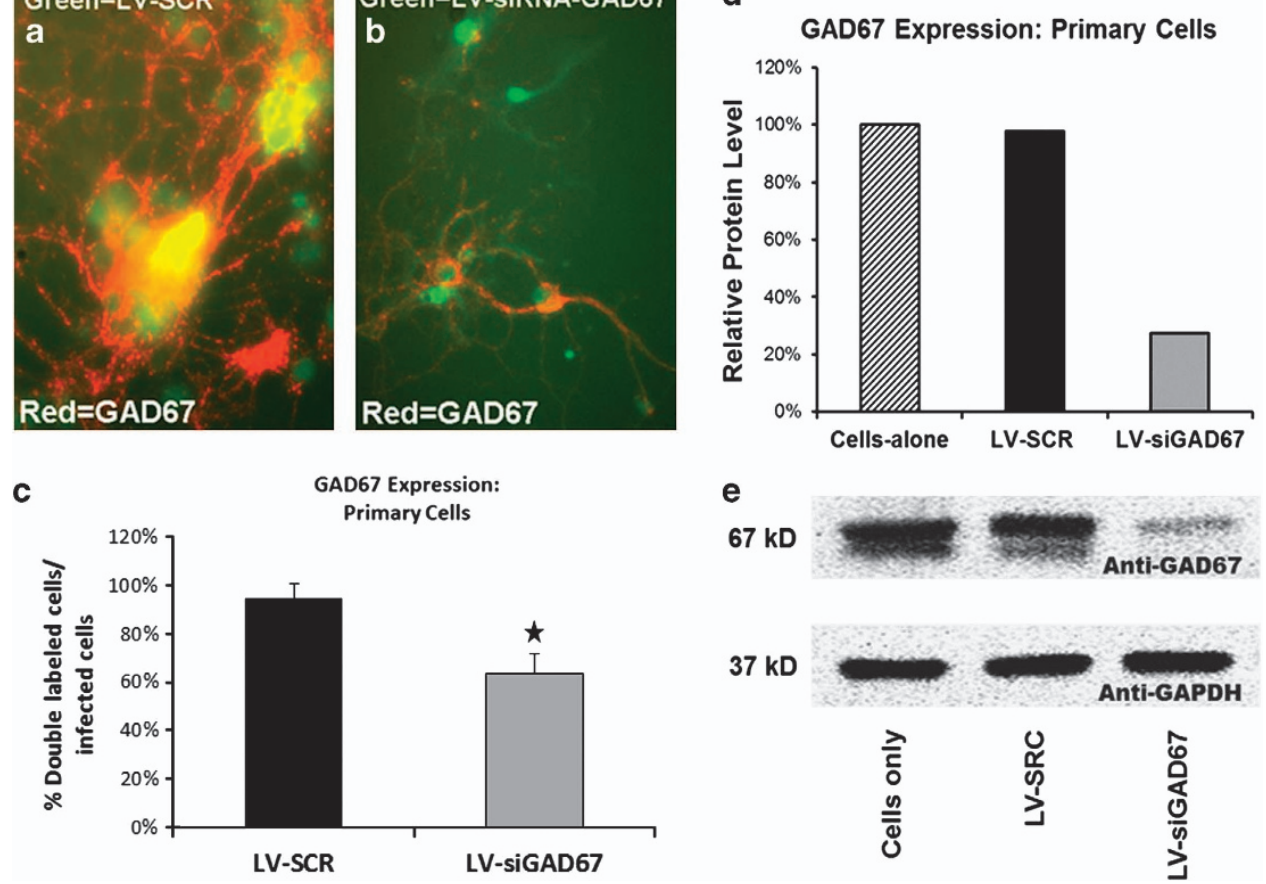

Figure 1 In vitro validation of lentiviral (LV)-siGAD67 virus. Image depicting primary cultures of hippocampal neurons from C57BL/6J mice (P10) infected with LV-SCR (a) or LV-siGAD67 (b). Overlay of fluorescence immunocytochemistry for GAD67 (red) in same field as in green fluorescent protein (GFP; green). Expression of GFP illustrates viral infectivity. These overlays illustrate the reduced expression of GAD67 signal from cells infected with LV-siGAD67 compared with LV-SCR. (c) Level of GAD67 expression was quantified by dividing the number of double label cells (GFP + GAD67) divided by infected cells (GFP). (d, e) Western blot processing of cells harvested from plate cultures revealed that LV-siGAD67-infected cells qualitatively expressed significantly less GAD67 protein than control-infected cells. (d) Western blot analysis of GAD67 protein levels from cell homogenates. Protein amounts determined from these western blots were normalized to levels of a GAPDH to loading control and expressed as percentages with reference to cells-alone control. (e) Digital image example of the western blot membrane showing protein bands of GAD67 and GAPDH protein in noninfected cells (cells alone), LV-SCR and LV-siGAD67-infected cells. Error bars denote 1 standard error of the mean (s.e.m.) Star indicates that the difference was statistically significant, $P<0.05$.

wells infected with LV-SCR and stained with anti-GAD67 (red) showed prevalent expression of GAD67. Antibodystained wells of LV-siGAD67 revealed considerably less GAD67 staining (Figure 1b). A total of 764 cells were examined for GAD67 and/or GFP fluorescent expression ( $\operatorname{siGAD67}=512, \mathrm{SCR}=252$ ), of which $\sim 32 \%$ expressed GFP. When compared with LV-SCR wells, the percent of GFP-positive cells that also expressed GAD67 was significantly less in LV-siGAD67 wells, $\chi^{2}(1, N=764)=5.09$, $P=0.02$ (Figure 1c). Western blot processing of cells harvested from plate cultures revealed that LV-siGAD67infected cells qualitatively expressed significantly less GAD67 protein than control-infected cells (Figures 1d and e).

Efficiency of GAD67 mRNA knockdown within the BLA. After the conclusion of the behavioral testing, the levels of protein or mRNA expression were examined in LV-infected mice to assess whether viral infections successfully induced GAD67 knockdown in vivo. In situ hybridization analyses for GAD65 and GAD67 mRNA were conducted on coronal brains sections obtained from half of the experimental animals ( $n=10$ per group). Figure $2 a$ illustrates the qualitative decrease of GAD67 mRNA expression within the amygdala following LV infection. Nissl-stained sections revealed that injection sites were centered in the BLA with an anterior-posterior range of $\sim-1.2$ to $-2.0 \mathrm{~mm}$ with reference to bregma. Stained sections also exhibited intact cellular and regional morphology at the site of injection, with no clear evidence of cell death or degradation. Quantitative evaluation of GAD67 mRNA levels in LV-siGAD67 and LVSCR-infected mice indicated that LV-siGAD67 mice expressed significantly less mRNA in the BLA when compared with LV-SCR controls (Figure 2b). LV-siGAD67 mice also showed less mRNA expression in the central nucleus of the amygdala (CE), but the group difference was not reliably significant. With reference to LV-SCR control animals, the relative expression levels of GAD67 mRNA within the BLA and CE of LV-siGAD67-infected animals were 65 and $87 \%$, respectively. GAD65 mRNA in the BLA was $126 \%$ in LV-siGAD67 mice with reference to controls. To examine protein levels, amygdala brain punches were obtained in remaining half of the experimental animals ( $n=10$ per group) and homogenized samples were subjected to western immunoblot analysis. As seen in Figure 2c, immunoblot analysis indicated that LV-siGAD67 effectively knocked down targeted protein in vivo, relative to LV-SCR $t(18)=2.67, P<0.05$.

GAD67 knockdown does not affect open field motor activity. Two weeks after stereotaxic infection of lentivirus targeting the bilateral amygdala, mice were subjected to a behavioral battery. Before fear conditioning, LV-infected 

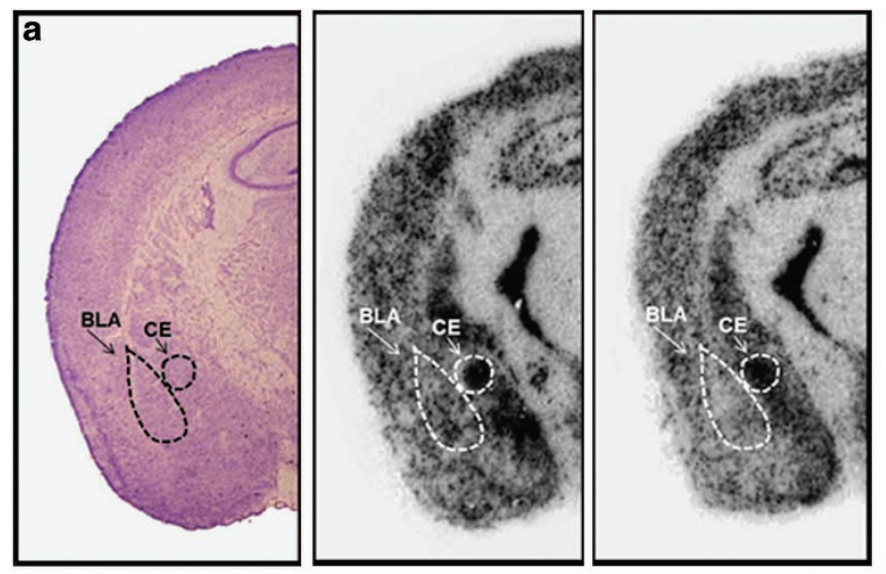

b
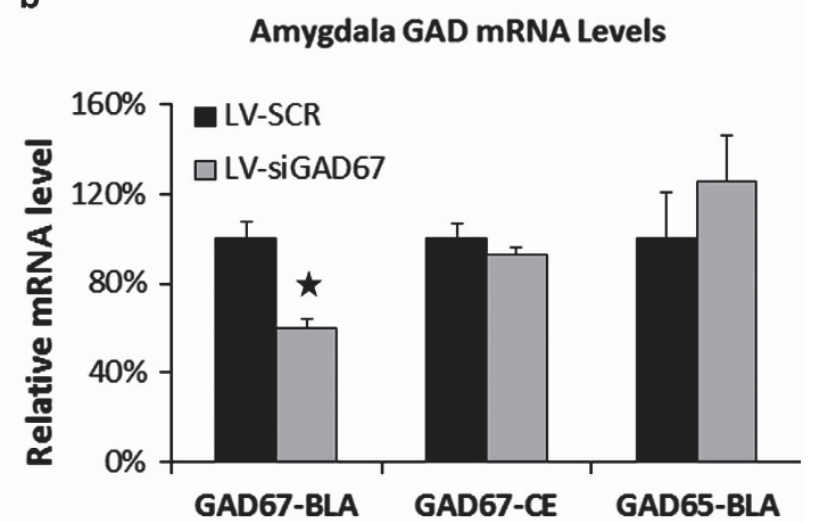

\section{GAD67 Expression: Amygdala}

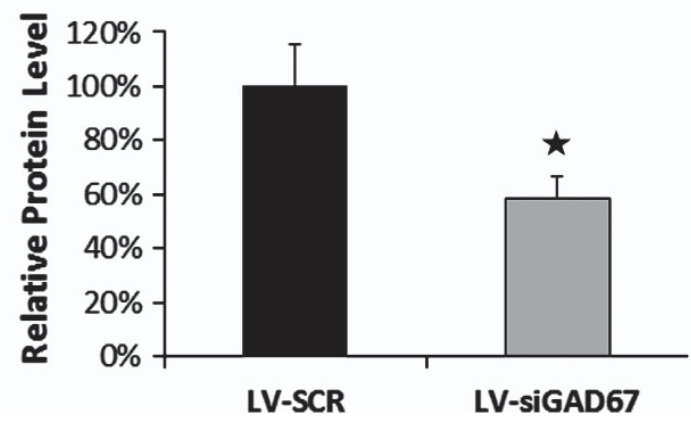

Figure 2 Reduction in GAD67 mRNA and protein in the amygdala. Levels of protein or mRNA expression were examined in lentiviral (LV)-infected mice 5 days after behavioral testing. In situ hybridization analyses for GAD65 and GAD67 mRNA were conducted on coronal brains sections obtained from half of the experimental animals ( $n=10$ per group). Amygdala brain punches were obtained in remaining half of the experimental animals ( $n=10$ per group) and homogenized samples were subjected to western immunoblot analysis. (a) Qualitative figure showing in situ hybridization of GAD67 mRNA in the basolateral complex of amygdala (BLA) and central nucleus of the amygdala (CEA) following a LV-SCR injection (middle) or LV-siGAD67 injection (right). Also included is a representative Nissl-stained section of LV-infected animal (left). (b, c) LV-siGAD67 mice expressed significantly less GAD67 mRNA and protein when compared with LV-SCR controls. (b) Relative GAD67 mRNA expression (BLA and CEA regions) and GAD65 mRNA expression (BLA only) in LV-SCR and LV-siRNA-infected mice. mRNA levels are expressed as percentages with reference to LV-SCR control animals. (c) Western blot analysis of GAD67 protein levels from amygdala tissue homogenates. Protein amounts determined by western blots were normalized to levels of a GAPDH to loading control and expressed as percentages with reference to LV-SCR control animals. Error bars denote 1 standard error of the mean (s.e.m.). Stars indicated that the difference was statistically significant, $P<0.05$.

mice were tested in the open field maze to determine whether GAD67 knockdown affected baseline motor activity. As seen in figure Figure 3a, both LV-siGAD67 and SCR mice showed similar levels of activity when measured for $30 \mathrm{~min}$ Overall, both groups showed a decrease in activity during the 30-min session, $\mathrm{F}(1,39)=82.58, P<0.01$; however, neither the main effect of group, $\mathrm{F}(1,39)=1.16, P>0.05$, or group $\times$ block interaction, $F(1,39)=0.32, P>0.05$, were significant. An independent $t$-test revealed no group differences in the time mice spent in the central zone of the open field, $t(39)=0.89, P>0.05$, suggesting no differences in basal anxiety levels. The mean percentages of time in the central zone (with standard error of the mean in parentheses) for LVsiGAD67 and LV-SCR groups were $43.5 \%(4.5)$ and $38.6 \%$ (3.4), respectively.

GAD67 knockdown impairs the anxiolytic-like effects of diazepam in the EPM test. To examine whether GAD67 knockdown affected the anxiolytic-like effects of diazepam, both LV-siGAD67 and LV-SCR animals were divided into two groups that received either diazepam $\left(1.5 \mathrm{mg} \mathrm{kg}^{-1}\right)$ or vehicle
30 min before EPM testing ( $n=10$ per group). As seen in Figures $3 \mathrm{~b}$ and $\mathrm{c}$, comparisons of vehicle- with diazepamtreated animals revealed a number of significant effects. An examination of the percentage of open arm time detected significant effects of group, treatment and group $\times$ treatment interaction. Overall, the percentage in open arm time was greater for diazepam-treated animals, $F(1,37)=11.0$, $P<0.05$, revealing the general anxiolytic-like effects of diazepam. In general, the percentage in open arm time was greater in LV-SCR compared with LV-siGAD67 mice, $\mathrm{F}(1,37)=4.7, P<0.05$. Analyses of the group $\times$ treatment interaction, $F(1,37)=4.3, P<0.05$, indicated that vehicletreated LV-siGAD67 and SCR animals showed similar percentages in open arm entries, $t(39)=0.15, P>0.05$. In diazepam-treated animals, the percentage in open arm time exhibited by LV-SCR mice was significantly greater than LVsiGAD67 mice, $t(39)=2.30, P<0.05$, indicating that diazepam induced a greater anxiolytic effect in SCR compared with LV-siGAD67 mice.

Also consistent with the anxiolytic-like effects of diazepam, the percentage of open arm entries was greater in diazepam- 

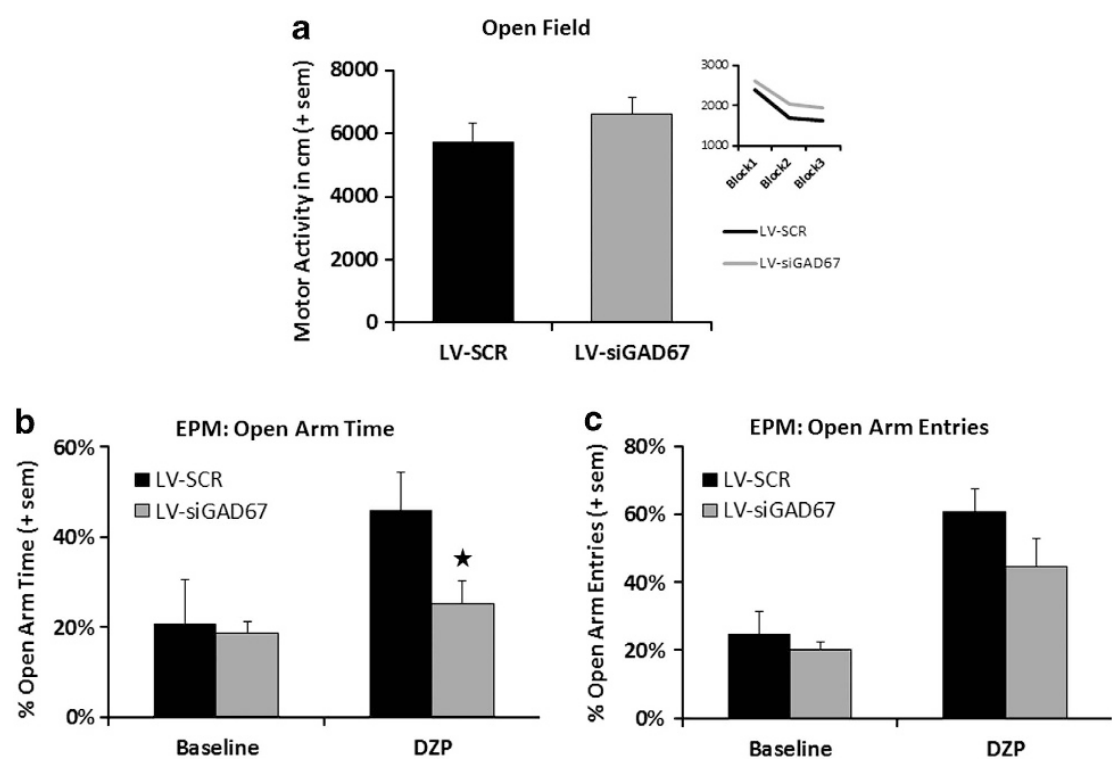

Figure 3 Baseline activity and the effects of diazepam on elevated plus maze (EPM) performance. lentiviral (LV)-siGAD67 ( $n=20)$ and LV-SCR ( $n=20)$ mice showed no differences in baseline motor activity before EPM and fear testing. (a) Baseline motor activity was measured by examining the total ambulatory distance (in $\mathrm{cm}$ ) during the 30-min open field test session. The inset panel displays the mean activity of each group in 10-min blocks. (b, c) The anxiolytic effects of diazepam are significantly blunted in mice with GAD67 knockdown in the amygdala (LV-siGAD67) as measured by percentage of open arm time in the EPM. Half of each surgery group (ns $=10$ ) received $1.5 \mathrm{mg} \mathrm{kg}^{-1}$ per i.p. of diazepam 30 min before testing. The second half of each group $(\mathrm{ns}=10)$ received vehicle. Bar graphs show the $(\mathbf{b})$ percentage of open arm time and (c) percentage of open arm entries on the EPM. Error bars denote 1 standard error of the mean (s.e.m.). Star indicates that the difference between groups was statistically significant $(P<0.05)$.

treated animals versus animals that received vehicle, as denoted by a significant treatment effect. The main effect of group across treatments was marginally nonsignificant, $\mathrm{F}(1,37)=3.28, P=0.08$, and the group $\times$ treatment interaction was statistically nonsignificant, $\mathrm{F}(1,37)=1.39, P>0.05$. Assessment of total closed arm entries indicated significant differences in locomotor activity among treatments, $F(3,30)=8.33, P<0.01$. Diazepam-treated animals made significantly more closed arm entries than the vehicle group, indicating a drug-induced increase in exploratory/motorstimulant activity. The mean closed arm entries (with standard error of the mean in parentheses) for vehicle- and diazepamtreated animals were $6.7(0.87)$ and $22.6(0.85)$, respectively. No differences in the number of closed arm entries were observed between groups at each level of treatment ( $P$ values $>0.05)$. Thus, observed group differences in the percentage of open arm time cannot be attributed to differences in locomotor activity.

GAD67 knockdown does not affect the acquisition or retention of conditioned freezing. We next examined whether GAD67 knockdown in amygdala would affect acquisition or expression of conditioned fear. Fear training to an auditory cue was performed in a Med Associates conditioning chamber and fear testing was performed in a modified context to reduce contextual fear. During the conditioning phase of the session, freezing scores similarly increased from the first to the last CS presentation in both groups as shown in Figure $4 a$. The ANOVA showed a significant main effect of trial, $\mathrm{F}(4,39)=32.4, P<0.01$, but no group effect or group $\times$ trial interaction, $F$-values $<1.0$, $P$-values $>0.05$. When tested $24 \mathrm{~h}$ after conditioning, both
LV-siGAD67 and LV-SCR mice displayed similar levels of tone CS freezing to the unreinforced CS, $t(39)=0.78$, $P>0.05$, signifying that the retention of fear was similar in both groups (Figure $4 b$ ).

GAD67 knockdown impairs extinction of conditioned fear. Following the first cued fear retention test, mice were repeatedly tested for five additional test sessions with the unreinforced auditory CS to examine the extinction of fear. As illustrated in Figure 4c, LV-siGAD67 mice showed higher levels of fear during repeated testing when compared with controls. Repeated-measure analysis of groups across test sessions exposed significant effects of group and session, F-values $<1.0, \quad P$-values $>0.05$. Although there were no differences between initial levels of conditioned fear on test 1 , there were significant differences between the levels of conditioned freezing on test 2 , test 3 and test 4 of extinction sessions, ts $(39)>2.48, P$-values $<0.02$. No differences in fear levels were observed on extinction tests 5 or 6 , ts $(39)<1.30, P$-values $>0.05$.

\section{Discussion}

The present study first sought to determine whether the knockdown of GAD67 in the amygdala would modulate the acquisition and extinction of conditioned fear. Both LVsiGAD67 and LV-SCR groups showed similar increases in conditioned fear during training; thus, the reduction of amygdala GAD67 produced no apparent changes in the acquisition of fear as measured by conditioned freezing. Following cued fear acquisition, mice were repeatedly tested over 5 days with the unreinforced auditory cue to examine 

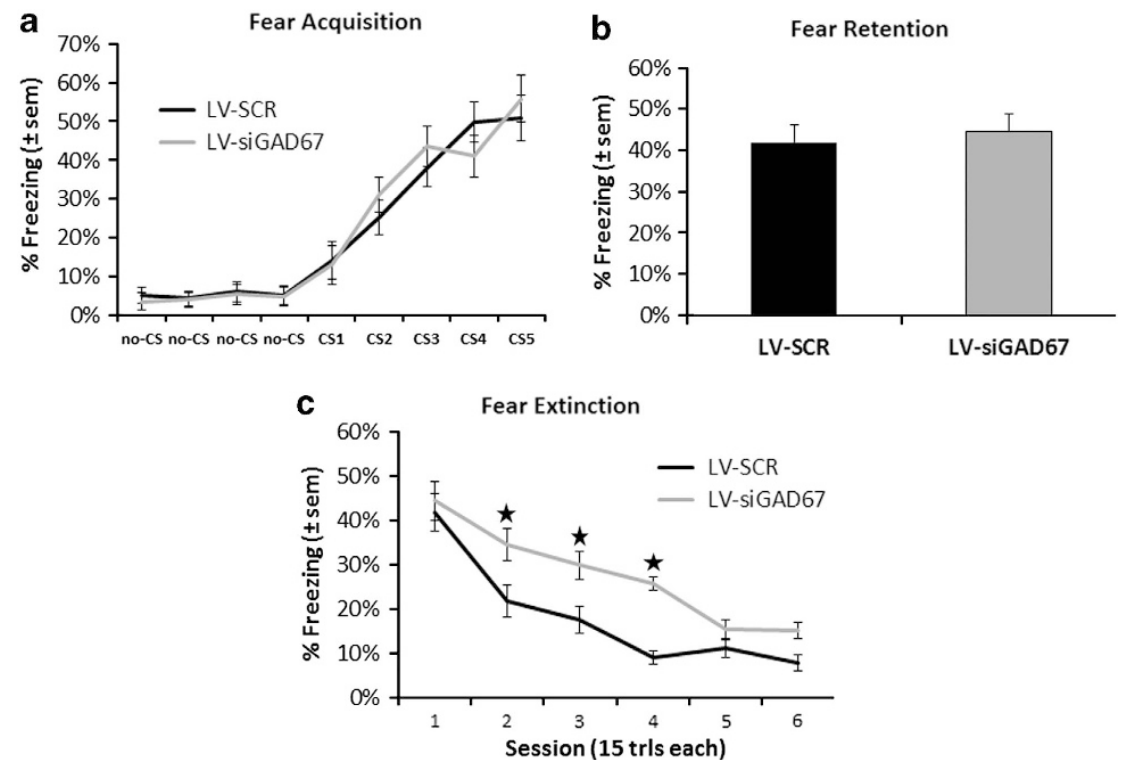

Figure 4 Conditioned fear and extinction in mice with amygdala GAD67 knockdown. (a) Acquisition of conditioned fear to auditory conditioned stimulus (CS) + shock pairing as measured by freezing. There was no difference in acquisition of fear in animals receiving bilateral amygdala injections of LV-SCR or LV-siGAD67. (b) Animals were tested $24 \mathrm{~h}$ after training to examine the retention of conditioned fear (session 1 extinction). There was no difference between the groups on level of conditioned fear. (c) Percent conditioned freezing is graphed for sessions 1-6 of extinction tests. Mice infected with LV-SCR demonstrate significant greater decreases in their level of conditioned fear, compared with LV-siGAD67-infected mice. Impaired extinction of fear, measured by percentage of freezing, is evident across multiple testing sessions. Error bars denote 1 standard error of the mean (s.e.m.). Star indicates that the difference between virus groups was statistically significant $(P<0.05)$.

subsequent retention and extinction of fear to the conditioned stimuli. Groups showed no differences in fear on the initial test, suggesting similar levels of fear retention. However, there were significant differences between the levels of conditioned fear on succeeding tests. Overall, mice with targeted amygdala GAD67 knockdown showed higher levels of fear on subsequent extinction sessions. Together, these data suggest that although there does not appear to be a direct effect of GAD67 knockdown on acquisition or retention of conditioned fear, there is an impairment of extinction of conditioned fear measured with freezing.

It is important to note that GAD67 is also expressed in glial cells as well as neurons. ${ }^{59}$ Furthermore, VSV-G-pseudotyped lentiviral vectors carrying a CMV promoter can express transgenes in both cell subsets. ${ }^{60}$ Thus, it is possible that decreased GAD67 levels in glial cells may have also contributed to our results. However, past studies have revealed that the percentage of glial cells transduced by lentiviruses is relatively low compared with neurons. ${ }^{61,62}$ Future research using lentiviral vectors with neuron-specific promoters that induce GAD67 knockdown in different interneuron classes (for example, somatostatin, cholecystokinin, parvalbumin) may help in determining the distinctive roles of GAD67 in specific interneuron types and glial cells.

Amygdala GAD67 and fear conditioning. Although GABAergic mechanisms have been implicated in numerous amygdala-dependent functions including learning, memory and anxiety, studies have not yet definitively demonstrated that the reduction of endogenous GAD activity within the amygdala is causal relative to the behaviors being tested. GAD67-/- mice show significant loss of the GABA function throughout the brain and die perinatally. ${ }^{37,63}$
Knockout mice lacking GAD65 display altered conditioned fear behavior; ${ }^{64,65}$ however, these mutants display decreased GAD65 throughout the brain and developmental alteration in cortical plasticity. ${ }^{66,67}$ Pavlovian conditioning appears to alter both isoforms of GAD as well as GABA. For example, tone fear conditioning results in a significant reduction of extracellular GABA levels in the amygdala during subsequent re-exposure to the tone $C S .{ }^{31}$ Likewise, the expression of GAD65 is significantly reduced in the amygdala after fear-conditioning training. ${ }^{32,65}$ The inhibition of CS-elicited conditioned responses associated with extinction are in part thought to be mediated by circuits activating or strengthening GABAergic transmission in the amygdala; ${ }^{68-70}$ thus, the increase in GAD activity may represent a mechanism that enables enhanced inhibitory control of fear responses. The above findings are also particularly relevant in the light of past studies showing pharmacological treatments that increase the excitability of amygdala by decreasing GABA transmission facilitate conditioned fear responses. ${ }^{71}$ We have previously reported that levels of GAD67 mRNA in the amygdala also decrease after the acquisition Pavlovian fear; whereas, fear extinction produces a training-induced increase in GAD67 mRNA transcript levels. Unpredictably, the reduction of GAD67 mRNA and protein did not significantly influence the acquisition of conditioned fear in the current study. It is possible that freezing levels in Figure 4a reflect a behavioral 'ceiling effect' that thwarted detection of group differences during acquisition. Accordingly, we cannot completely rule out the possibility that levels of GAD67 mRNA and/or protein significantly affect fear acquisition. In such case, group differences in levels of freezing during extinction sessions may be due to different pre-extinction fear levels. Future 
experiments including lower shock US levels, fewer training trials or different indices of fear (for example, fear-potentiated startle) may evaluate this possibility. It must also be noted that although alterations in mRNA concentrations are widely used as a surrogate for changes in protein, in vivo mRNA levels obviously do not necessarily correlate with protein levels. Numerous posttranscriptional mechanisms regulate the rate, timing and amount of the encoded protein (see below).

Amygdala GAD67 and anxiety. Our study also examined whether a reduction of amygdala GAD67 would result in an increased anxiety-like behavior and decrease the anxiolyticlike effect of diazepam as measured in the open field and EPM. Because a decrease in GABAergic transmission is associated with an anxiogenic-like profile in rodents, we hypothesized that LV-induced silencing of amygdala GAD67 would result in an anxiogenic-like profile. However, in the absence of diazepam, we found that LV-siGAD67 and LV-SCR groups showed similar EPM and open field performance. These findings contrast with previous data, suggesting that a reduction of central GAD produces an anxiogenic-like phenotype in mice. For example, GAD65deficient mice exhibit increased anxiety-like behaviors, ${ }^{72}$ which are attributed to reduced GABAergic neurotransmission in the amygdala and hippocampus. ${ }^{73}$ However, these mutants also demonstrate increases in spontaneous seizures and are sensitive to drug-induced seizures, ${ }^{37}$ suggesting that the GAD deficits in other brain regions may also contribute to anxiety-like profile. A decrease in amygdala GAD67 may be compensated for by an increased extrasynaptic GABAAR function, as proposed for deletion of Gad65. ${ }^{74}$ On the other hand, mice selectively bred to display high levels of anxiety-related behavior show marked increases in the expression of GAD65 and GAD67 mRNAs and GABA. ${ }^{75,76}$ The increased expression of GADs may be a developmental mechanism to compensate for persistent activation of the amygdala in highanxiety mice.

Amygdala GAD67 and behavioral sensitivity to diazepam. While amygdala down-regulation of GAD67 produced no measureable changes in anxiety-like behavior, it did reduce the behavioral sensitivity for diazepam as assessed in the EPM. These results are consistent with past studies that show GAD65 KO mice display diminished behavioral responses to BZs and barbiturates. ${ }^{73,74}$ Human studies have revealed that patients suffering from anxiety disorders have blunted behavioral responses to $B Z$ administration and have diminished central BZ binding. ${ }^{2,9}$ GAD67 provides the magnitude of basal GABA for inhibitory neurotransmission; ${ }^{77,78}$ thus, a reduction in the occupancy of GABAARs by GABA is a simple explanation for the diminished diazepam potency in LVsiGAD67 mice. Changes in the allosteric interactions between the GABA and BZ binding sites may also account for the reduced behavioral sensitivity to diazepam. In vivo changes in GABA concentrations and receptor modulators are known to induce homologous uncoupling. ${ }^{79-83}$ A variety of transcriptional mechanisms, including alteration in the transcription of GABAAR subunit genes, play a role in neuro-adaptive processes underlying uncoupling. ${ }^{84-87}$ Thus, it is conceivable that GAD67 down-regulation leads to altered subtype expression or posttranslational receptor modifications that reduce agonist effects of diazepam.

The influence of GAD67 inhibition on GABA release. A reduction in GAD67 may decrease inhibitory transmission by influencing vesicular as well as nonvesicular release of GABA. The majority of GAD67 in the brain is present in the constitutively active state ${ }^{88-90}$ and is targeted to synapses, axons and dendrites. ${ }^{35}$ GAD67 is recognized for fulfilling metabolic demands of neurons and the synthesis of GABA for nonvesicular release through GABA transporters, which can be induced to operate in a reverse direction. ${ }^{91-94}$ The role of GAD67 in the synthesis and transport of GABA into synaptic vesicles is unclear. Past studies have recognized that the structural and functional coupling between GAD65 and vesicular GABA transporter mediates the synthesis and transport of GABA into synaptic vesicles. ${ }^{95,96}$ However, recent evidence suggests that GAD67, like GAD65, forms large clusters in presynaptic termini of inhibitory interneuron and may also synthesize GABA from glutamate and transport this newly made transmitter into synaptic vesicles. ${ }^{95,97,98}$ Consistent with this, subcellular fractionation of brains from GAD65 KO mice reveals that GAD67 is localized in presynaptic clusters in the absence of GAD65. ${ }^{99,100}$ Thus, the reduction in GAD67 in the current study may decrease vesicular along with nonvesicular release of GABA.

Amygdala GABAergic transmission. In the amygdala, synaptic release of GABA plays a crucial role in controlling pyramidal neuron excitability and responsiveness through feedforward, feedback and tonic inhibition. ${ }^{18,101-105}$ Local inhibitory interneurons in the BLA predominantly terminate on $\alpha 1-, \alpha 2-$ and $\alpha 3$-containing GABAARs located on pyramidal projection neurons. ${ }^{18,106-110}$ Pyramidal cells also contain extrasynaptic $\alpha 4-G A B A A R s$, which are tonically activated by ambient GABA and are important for controlling basal neuronal excitability. ${ }^{109}$ Recent evidence indicates that a reduction of $\alpha 1$-GABAARs in the BLA does not affect baseline anxiety-like behavior or the anxiolytic-like activity of diazepam as assessed using the EPM model. ${ }^{42}$ Thus, the reduction of GABA-mediated activation of $\alpha 2-$ and $\alpha 3-$ GABAARs could explain the attenuated behavioral sensitivity to diazepam seen in the current study. Consistent with this hypothesis, experimental data from genetically altered mice and subtype-selective ligands indicate that the $\alpha 1-G A B A A R$ subtype is involved in sedative and amnesic processes, whereas the $\alpha 2-$ and $\alpha 3-$ GABAARs are specifically involved in anxiety. ${ }^{111,112}$ It should also be mentioned that the release of GABA in the BLA can suppress glutamatergic afferents via presynaptic GABABRs. ${ }^{113,114}$

Although GAD67 mRNA levels in the central nucleus of the amygdala $(\mathrm{CeA})$ were not significantly reduced, it is unclear whether LV-siGAD67 injections reduced mRNA levels in intercalated (ITC) amygdala neurons that are located between the BLA and the CeA. ${ }^{115}$ ITC cells of the amygdala are densely packed inhibitory neurons that send efferent projections into $\mathrm{CeA}$ that contains $\alpha 2$ and $\alpha 3-\mathrm{GABAA}$ subtypes. These neurons are innervated by excitatory inputs from the 
$\mathrm{BLA}^{116,117}$ and infralimbic cortex ${ }^{118-121}$ which have both been implicated in mediating the extinction of conditioned fear. ${ }^{69,122}$ A reduction of GABA in these ITC neurons could explain the extinction deficit seen in the current study. Our analyses have also not examined whether the GAD67 reduction reflects an overall reduction in interneurons or a selective reduction in one or more interneuron subtypes. Important tasks of future studies therefore will be to examine these possible influences on our current findings.

\section{Alterations in GAD67 and the regulation of synaptic plasticity in GABAergic transmission. The mechanisms} that regulate the development and structural plasticity of GABAergic neurotransmission remain poorly understood. Many studies indicate that activity-dependent alterations in GAD67 may play a role in the plasticity of inhibitory synaptic connections. The expression of GAD mRNAs is known to be regulated by neuronal activity, so that tonically firing GABAergic neurons express high amounts of GAD and particularly GAD67 mRNA and protein. In hippocampal GABAergic neurons, activity-dependent upregulations of GAD65 and GAD67 mRNA and protein are observed following kainate- or pilocarpine-induced seizures. ${ }^{40,123-125}$ This seizure-induced plasticity may reflect a compensatory upregulation in the subpopulation of surviving GABA neurons to control the increased excitability of the region; ${ }^{123,126-128}$ however, similar increases are seen in the absence of epileptic activity or neuronal loss. ${ }^{129}$ Similarly, direct in vitro kindling of the dentate gyrus results in the emergence of fast GABAergic transmission that coincides with the expression of GAD67 and vesicular GABA transporter mRNA. ${ }^{130}$ Conversely, withdraw of cortical circuits from their normal excitatory inputs results in the downregulation of GAD67 mRNA and GABA levels. ${ }^{131,132}$ Evidence suggests that the efficacy of GABA-mediated mIPSCs can be up- and downregulated in response to altered levels of activity in neuronal networks. ${ }^{36}$ Together, these studies indicate that activitydependent and bi-directional alterations in GAD67 and GABA metabolism provide a mechanism for activity-dependent regulation of inhibitory synaptic plasticity.

In summary, this study demonstrates that the reduction of GAD67 in the amygdala of adult mice results in a deficit in the extinction, but not the acquisition or retention, of conditioned fear. Furthermore, amygdala GAD67 reduction blunts the anxiolytic-like effects of diazepam without affecting basal anxiety levels. Studies performed in humans and animal models have implicated alterations in GABAergic transmission may participate in anxiety disorders. Our findings suggest that changes in basal and/or activity-dependent levels of amygdala GAD67 may be important in mediating some of the symptoms associated with anxiety disorders.

\section{Conflict of interest}

The authors declare no conflict of interest.

Acknowledgements. This study was supported by NIH (DA019624, P30 NS055077, F32 MH073389), NARSAD, the Burroughs Wellcome Fund, and Center for Behavioral Neuroscience STC Center: NSF Agmt \#IBN-9876754, National Primate Research Center base Grant \#RR-00165, Animal Resource Program at NIH.
1. Tiihonen J, Kuikka J, Rasanen P, Lepola U, Koponen H, Liuska A et al. Cerebral benzodiazepine receptor binding and distribution in generalized anxiety disorder: a fractal analysis. Mol Psychiatry 1997; 2: 463-471.

2. Bremner JD, Innis RB, Southwick SM, Staib L, Zoghbi S, Charney DS. Decreased benzodiazepine receptor binding in prefrontal cortex in combat-related posttraumatic stress disorder. Am J Psychiatry 2000; 157: 1120-1126.

3. Bremner JD, Innis RB, White T, Fujita M, Silbersweig D, Goddard AW et al. SPECT [l-123]iomazenil measurement of the benzodiazepine receptor in panic disorder. Biol Psychiatry 2000; 47: 96-106.

4. Malizia AL, Cunningham VJ, Bell CJ, Liddle PF, Jones T, Nutt DJ. Decreased brain GABAA-benzodiazepine receptor binding in panic disorder: preliminary results from a quantitative PET study. Arch Gen Psychiatry 1998; 55: 715-720.

5. Schlegel S, Steinert H, Bockisch A, Hahn K, Schloesser R, Benkert O. Decreased benzodiazepine receptor binding in panic disorder measured by IOMAZENIL-SPECT. A preliminary report. Eur Arch Psychiatry Clin Neurosci 1994; 244: 49-51.

6. Kaschka W, Feistel H, Ebert D. Reduced benzodiazepine receptor binding in panic disorders measured by iomazenil SPECT. J Psychiatr Res 1995; 29: 427-434.

7. Kuikka JT, Pitkanen A, Lepola U, Partanen K, Vainio P, Bergstrom KA et al. Abnormal regional benzodiazepine receptor uptake in the prefrontal cortex in patients with panic disorder. Nucl Med Commun 1995; 16: 273-280.

8. Goddard AW, Mason GF, Almai A, Rothman DL, Behar KL, Petroff OAC et al. Reductions in occipital cortex GABA levels in panic disorder detected with $1 \mathrm{H}$-magnetic resonance spectroscopy. Arch Gen Psychiatry 2001; 58: 556-561.

9. Goddard AW, Mason GF, Appel M, Rothman DL, Gueorguieva R, Behar KL et al. Impaired GABA neuronal response to acute benzodiazepine administration in panic disorder. Am J Psychiatry 2004; 161: 2186-2193.

10. Roy-Byrne P, Wingerson DK, Radant A, Greenblatt DJ, Cowley DS. Reduced benzodiazepine sensitivity in patients with panic disorder: comparison with patients with obsessive-compulsive disorder and normal subjects. Am J Psychiatry 1996; 153: 1444-1449.

11. Roy-Byrne PP, Cowley DS, Greenblatt DJ, Shader RI, Hommer D. Reduced benzodiazepine sensitivity in panic disorder. Arch Gen Psychiatry 1990; 47: 534-538.

12. Vaiva G, Thomas P, Ducrocq F, Fontaine M, Boss V, Devos P et al. Low posttrauma GABA plasma levels as a predictive factor in the development of acute posttraumatic stress disorder. Biol Psychiatry 2004; 55: 250-254.

13. Vaiva G, Boss V, Ducrocq F, Fontaine M, Devos P, Brunet A et al. Relationship between posttrauma GABA plasma levels and PTSD at 1-year follow-up. Am J Psychiatry 2006; 163: $1446-1448$

14. Muller JF, Mascagni F, McDonald AJ. Postsynaptic targets of somatostatin-containing interneurons in the rat basolateral amygdala. J Comp Neurol 2007; 500: 513-529.

15. Klausberger T, Marton LF, O'Neill J, Huck JH, Dalezios Y, Fuentealba $P$ et al. Complementary roles of cholecystokinin- and parvalbumin-expressing GABAergic neurons in hippocampal network oscillations. J Neurosci 2005; 25: 9782-9793.

16. Freund TF, Gulyas Al. Inhibitory control of GABAergic interneurons in the hippocampus. Can J Physiol Pharmacol 1997; 75: 479-487.

17. McDonald AJ, Mascagni F. Parvalbumin-containing interneurons in the basolateral amygdala express high levels of the alpha1 subunit of the GABAA receptor. $J$ Comp Neurol 2004; 473: 137-146.

18. Klausberger T, Roberts JD, Somogyi P. Cell type- and input-specific differences in the number and subtypes of synaptic GABA(A) receptors in the hippocampus. I Neurosci 2002; 22: 2513-2521.

19. Somogyi $P$, Klausberger $T$. Defined types of cortical interneurone structure space and spike timing in the hippocampus. J Physiol 2005; 562(Pt 1): 9-26.

20. Pesold C, Treit D. The central and basolateral amygdala differentially mediate the anxiolytic effects of benzodiazepines. Brain Res 1995; 671: 213-221.

21. Green S, Vale AL. Role of amygdaloid nuclei in the anxiolytic effects of benzodiazepines in rats. Behav Pharmacol 1992; 3: 261-264.

22. Nunes-de-Souza RL, Canto-de-Souza A, da-Costa M, Fornari RV, Graeff FG, Pela IR. Anxiety-induced antinociception in mice: effects of systemic and intra-amygdala administration of 8-OH-DPAT and midazolam. Psychopharmacology (Berl) 2000; 150 300-310.

23. Gonzalez LE, Andrews N, File SE. 5-HT1A and benzodiazepine receptors in the basolateral amygdala modulate anxiety in the social interaction test, but not in the elevated plus-maze. Brain Res 1996; 732: 145-153.

24. Petersen EN, Braestrup C, Scheel-Kruger J. Evidence that the anticonflict effect of midazolam in amygdala is mediated by the specific benzodiazepine receptors. Neurosci Lett 1985; 53: 285-288.

25. Shibata S, Yamashita K, Yamamoto E, Ozaki T, Ueki S. Effects of benzodiazepine and GABA antagonists on anticonflict effects of antianxiety drugs injected into the rat amygdala in a water-lick suppression test. Psychopharmacology (Berl) 1989; 98: 38-44.

26. Hodges $\mathrm{H}$, Green S, Glenn B. Evidence that the amygdala is involved in benzodiazepine and serotonergic effects on punished responding but not on discrimination. Psychopharmacology (Berl) 1987; 92: 491-504.

27. Helmstetter FJ. Stress-induced hypoalgesia and defensive freezing are attenuated by application of diazepam to the amygdala. Pharmacol Biochem Behav 1993; 44: 433-438.

28. Harris JA, Westbrook RF. Effects of benzodiazepine microinjection into the amygdala or periaqueductal gray on the expression of conditioned fear and hypoalgesia in rats. Behav Neurosci 1995; 109: 295-304. 
29. Da Cunha C, Wolfman C, Levi de Stein M, Ruschel AC, Izquierdo I, Medina JH. Anxiogenic effects of the intraamygdala injection of flumazenil, a benzodiazepine recepto antagonist. Funct Neurol 1992; 7: 401-405.

30. Sanders SK, Shekhar A. Anxiolytic effects of chlordiazepoxide blocked by injection of GABAA and benzodiazepine receptor antagonists in the region of the anterior basolatera amygdala of rats. Biol Psychiatry 1995; 37: 473-476.

31. Stork O, Ji FY, Obata K. Reduction of extracellular GABA in the mouse amygdala during and following confrontation with a conditioned fear stimulus. Neurosci Lett 2002; 327 138-142.

32. Pape $\mathrm{HC}$, Stork $\mathrm{O}$. Genes and mechanisms in the amygdala involved in the formation of fear memory. Ann NY Acad Sci 2003; 985: 92-105.

33. Mahanty NK, Sah P. Calcium-permeable AMPA receptors mediate long-term potentiation in interneurons in the amygdala 1998; 394: 683-687.

34. Bauer EP, LeDoux JE. Heterosynaptic long-term potentiation of inhibitory interneurons in the lateral amygdala. J Neurosci 2004; 24: 9507-9512.

35. Soghomonian J-J, Martin DL. Two isoforms of glutamate decarboxylase: why? Trends Pharmacol Sci 1998; 19: 500-505.

36. Engel D, Pahner I, Schulze K, Frahm C, Jarry H, Ahnert-Hilger G et al. Plasticity of rat central inhibitory synapses through GABA metabolism. J Physiol 2001; 535(Pt 2): 473-482.

37. Asada $\mathrm{H}$, Kawamura $\mathrm{Y}$, Maruyama K, Kume H, Ding RG, Kanbara N et al. Cleft palate and decreased brain gamma-aminobutyric acid in mice lacking the $67-\mathrm{kDa}$ isoform of glutamic acid decarboxylase. Proc Natl Acad Sci USA 1997; 94: 6496-6499.

38. Condie BG, Bain G, Gottlieb DI, Capecchi MR. Cleft palate in mice with a targeted mutation in the $\gamma$-aminobutyric acid-producing enzyme glutamic acid decarboxylase 67 . Proc Natl Acad Sci 1997; 94: 11451-11455.

39. Asada H, Kawamura Y, Maruyama K, Kume H, Ding R, Ji FY et al. Mice lacking the $65 \mathrm{kDa}$ isoform of glutamic acid decarboxylase (GAD65) maintain normal levels of GAD67 and GABA in their brains but are susceptible to seizures. Biochem Biophys Res Commun 1996; 229: 891-895.

40. Freichel $\mathrm{C}$, Potschka $\mathrm{H}$, Ebert $\mathrm{U}$, Brandt $\mathrm{C}$, Löscher W. Acute changes in the neuronal expression of GABA and glutamate decarboxylase isoforms in the rat piriform cortex following status epilepticus. Neuroscience 2006; 141: 2177-2194.

41. Research IoLA, Sciences CoL, Council NR. Guide for the Care and Use of Laboratory Animals. The National Academies Press, 1996.

42. Heldt SA, Ressler KJ. Amygdala-specific reduction of alpha1-GABAA receptors disrupts the anticonvulsant, locomotor, and sedative, but not anxiolytic, effects of benzodiazepines in mice. J Neurosci 2010; 30: 7139-7151.

43. Tiscornia G, Singer O, Ikawa M, Verma IM. A general method for gene knockdown in mice by using lentiviral vectors expressing small interfering RNA. Proc Natl Acad Sci USA 2003; 100: 1844-1848.

44. Heldt SA, Stanek L, Chhatwal JP, Ressler KJ. Hippocampus-specific deletion of BDNF in adult mice impairs spatial memory and extinction of aversive memories. Mol Psychiatry 2007; 12: 656-670.

45. Tiscornia G, Singer O, Verma IM. Production and purification of lentiviral vectors Nat Protoc 2006; 1: 241-245.

46. Jasnow AM, Rainnie DG, Maguschak KA, Chhatwal JP, Ressler KJ. Construction of celltype specific promoter lentiviruses for optically guiding electrophysiological recordings and for targeted gene delivery. Methods Mol Biol 2009; 515: 199-213.

47. Rodgers RJ, Dalvi A. Anxiety, defence and the elevated plus-maze. Neurosci Biobehav Rev 1997; 21: 801-810.

48. Brewer GJ. Isolation and culture of adult rat hippocampal neurons. J Neurosci Methods 1997; 71: 143-155

49. Paxinos G, Franklin K. The Mouse Brain in Stereotaxic Coordinates. Academic Press: New York, 2001.

50. Võikar V, Vasar E, Rauvala H. Behavioral alterations induced by repeated testing in C57BL/6J and 129S2/Sv mice: implications for phenotyping screens. Genes Brain Behav 2004; 3: 27-38.

51. Mcllwain KL, Merriweather MY, Yuva-Paylor LA, Paylor R. The use of behavioral test batteries: effects of training history. Physiol Behav 2001; 73: 705-717

52. Markowitz GJ, Kadam SD, Boothe DM, Irving ND, Comi AM. The pharmacokinetics of commonly used antiepileptic drugs in immature CD1 mice. Neuroreport 2010; 21 452-456.

53. Greenblatt DJ, Sethy VH. Benzodiazepine concentrations in brain directly reflect receptor occupancy: studies of diazepam, lorazepam, and oxazepam. Psychopharmacology (Berl) 1990; 102: 373-378.

54. Hogg S. A review of the validity and variability of the Elevated Plus-Maze as an animal model of anxiety. Pharmacol Biochem Behav Anxiety Stress Depression 1996; 54: 21-30.

55. Pellow S, File SE. Anxiolytic and anxiogenic drug effects on exploratory activity in an elevated plus-maze: a novel test of anxiety in the rat. Pharmacol Biochem Behav 1986; 24: $525-529$.

56. Bradford MM. A rapid and sensitive method for the quantitation of microgram quantities of protein utilizing the principle of protein-dye binding. Anal Biochem 1976; 72: 248-254.

57. Ressler KJ, Paschall G, Zhou XL, Davis M. Regulation of synaptic plasticity genes during consolidation of fear conditioning. J Neurosci 2002; 22: 7892-7902.

58. Heldt SA, Ressler KJ. Training-induced changes in the expression of GABA(A)associated genes in the amygdala after the acquisition and extinction of Pavlovian fear. Eur J Neurosci 2007; 26: 3631-3644.
59. Lee M, Schwab C, McGeer PL. Astrocytes are GABAergic cells that modulate microglial activity. Glia 2011; 59: 152-165.

60. Miyoshi H, Blomer U, Takahashi M, Gage FH, Verma IM. Development of a selfinactivating lentivirus vector. J Virol 1998; 72: 8150-8157.

61. Jakobsson J, Ericson C, Jansson M, Bjork E, Lundberg C. Targeted transgene expression in rat brain using lentiviral vectors. J Neurosci Res 2003; 73: 876-885.

62. Yu H, Fischer G, Jia G, Reiser J, Park F, Hogan QH. Lentiviral gene transfer into the dorsal root ganglion of adult rats. Mol Pain 2011; 7: 63.

63. Gunther U, Benson J, Benke D, Fritschy JM, Reyes G, Knoflach F et al. Benzodiazepineinsensitive mice generated by targeted disruption of the gamma 2 subunit gene of gamma-aminobutyric acid type A receptors. Proc Natl Acad Sci USA 1995; 92: 7749-7753.

64. Stork O, Yamanaka H, Stork S, Kume N, Obata K. Altered conditioned fear behavior in glutamate decarboxylase 65 null mutant mice. Genes Brain Behav 2003; 2: 65-70.

65. Bergado-Acosta JR, Sangha S, Narayanan RT, Obata K, Pape HC, Stork O. Critical role of the $65-\mathrm{kDa}$ isoform of glutamic acid decarboxylase in consolidation and generalization of Pavlovian fear memory. Learn Mem 2008; 15: 163-171.

66. Wu H, Jin Y, Buddhala C, Osterhaus G, Cohen E, Jin $\mathrm{H}$ et al. Role of glutamate decarboxylase (GAD) isoform, GAD65, in GABA synthesis and transport into synaptic vesicles-evidence from GAD65-knockout mice studies. Brain Res 2007; 1154: 80-83.

67. Hensch TK, Fagiolini M, Mataga N, Stryker MP, Baekkeskov S, Kash SF. Local GABA circuit control of experience-dependent plasticity in developing visual cortex. Science 1998; 282: 1504-1508.

68. Maren S. Building and burying fear memories in the brain. Neuroscientist 2005; 11 : $89-99$

69. Myers KM, Davis M. Mechanisms of fear extinction. Mol Psychiatry 2007; 12: 120-150.

70. Akirav I, Maroun M. The role of the medial prefrontal cortex-amygdala circuit in stress effects on the extinction of fear. Neural Plast 200730873.

71. Davis M, Rainnie D, Cassell M. Neurotransmission in the rat amygdala related to fear and anxiety. Trends Neurosci 1994; 17: 208-214.

72. Kash SF, Tecott LH, Hodge C, Baekkeskov S. Increased anxiety and altered responses to anxiolytics in mice deficient in the $65-\mathrm{kDa}$ isoform of glutamic acid decarboxylase. Proc Natl Acad Sci 1999; 96: 1698-1703.

73. Kash SF, Johnson RS, Tecott LH, Noebels JL, Mayfield RD, Hanahan D et al. Epilepsy in mice deficient in the $65-\mathrm{kDa}$ isoform of glutamic acid decarboxylase. Proc Natl Acad Sci USA 1997; 94: 14060-14065.

74. Blednov YA, Walker DL, lyer SV, Homanics G, Harris AR. Mice lacking Gad2 show altered behavioral effects of ethanol, flurazepam and gabaxadol. Addict Biol 2010; 15: $45-61$

75. Krömer SA, Keßler MS, Milfay D, Birg IN, Bunck M, Czibere $L$ et al. Identification of glyoxalase-l as a protein marker in a mouse model of extremes in trait anxiety. J Neurosci 2005; 25: 4375-4384.

76. Tasan RO, Bukovac A, Peterschmitt YN, Sartori SB, Landgraf R, Singewald N et al. Altered GABA transmission in a mouse model of increased trait anxiety. Neuroscience 2011; 183: 71-80.

77. Tian N, Petersen C, Kash S, Baekkeskov S, Copenhagen D, Nicoll R. The role of the synthetic enzyme GAD65 in the control of neuronal $\gamma$-aminobutyric acid release. Proc Natl Acad Sci 1999; 96: 12911-12916.

78. Patel AB, De Graaf RA, Martin DL, Battaglioli G, Behar KL. Evidence that GAD65 mediates increased GABA synthesis during intense neuronal activity in vivo. J Neurochem 2006; 97: 385-396.

79. Follesa P, Serra M, Cagetti E, Pisu MG, Porta S, Floris S et al. Allopregnanolone synthesis in cerebellar granule cells: roles in regulation of GABAA receptor expression and function during progesterone treatment and withdrawal. Mol Pharmacol 2000; 57 : 1262-1270.

80. Klein RL, Whiting PJ, Harris RA. Benzodiazepine treatment causes uncoupling of recombinant GABAA receptors expressed in stably transfected cells. J Neurochem 1994; 63: 2349-2352.

81. Friedman LK, Gibbs TT, Farb DH. [gamma]-Aminobutyric acidA receptor regulation: heterologous uncoupling of modulatory site interactions induced by chronic steroid, barbiturate, benzodiazepine, or GABA treatment in culture. Brain Res 1996; 707: 100-109.

82. Ali NJ, Olsen RW. Chronic benzodiazepine treatment of cells expressing recombinant GABAA receptors uncouples allosteric binding: studies on possible mechanisms. J Neurochem 2001; 79: 1100-1108.

83. Grobin AC, Fritschy J-M, Morrow AL. Chronic ethanol administration alters immunoreactivity for GABAA receptor subunits in rat cortex in a region-specific manner. Alcoholism Clin Exp Res 2000; 24: 1137-1144.

84. Xiang K, Tietz El. Chronic benzodiazepine-induced reduction in GABAA receptormediated synaptic currents in hippocampal $C A 1$ pyramidal neurons prevented by prior nimodipine injection. Neuroscience 2008; 157: 153-163.

85. Lippa A, Czobor P, Stark J, Beer B, Kostakis E, Gravielle M et al. Selective anxiolysis produced by ocinaplon, a GABAA receptor modulator. Proc Natl Acad Sci USA 2005; 102: 7380-7385.

86. Lyons HR, Land MB, Gibbs TT, Farb DH. Distinct signal transduction pathways for GABAinduced GABAA receptor down-regulation and uncoupling in neuronal culture: a role for voltage-gated calcium channels. J Neurochem 2001; 78: 1114-1126. 
87. Miranda JD, Barnes EM. Repression of $\gamma$-aminobutyric acid type A receptor $\alpha 1$ polypeptide biosynthesis requires chronic agonist exposure. J Biol Chem 1997; 272: 16288-16294.

88. Fenalti G, Law RHP, Buckle AM, Langendorf C, Tuck K, Rosado CJ et al. GABA production by glutamic acid decarboxylase is regulated by a dynamic catalytic loop. Nat Struct Mol Biol 2007; 14: 280-286.

89. Martin DL, Martin SB, Wu SJ, Espina N. Regulatory properties of brain glutamate decarboxylase (GAD)the apoenzyme of GAD is present principally as the smaller of two molecular forms of GAD in brain. J Neurosci 1991; 11: 2725-2731.

90. Mathews GC, Diamond JS. Neuronal glutamate uptake contributes to GABA synthesis and inhibitory synaptic strength. J Neurosci 2003; 23: 2040-2048.

91. Belhage B, Hansen GH, Schousboe A. Depolarization by K+ and glutamate activates different neurotransmitter release mechanisms in gabaergic neurons: vesicular versus non-vesicular release of GABA. Neuroscience 1993; 54: 1019-1034.

92. Dunlop J, Grieve A, Schousboe A, Griffiths R. Stimulation of $\gamma-[3 \mathrm{H}]$ aminobutyric acid release from cultured mouse cerebral cortex neurons by sulphur-containing excitatory amino acid transmitter candidates: receptor activation mediates two distinct mechanisms of release. J Neurochem 1991; 57: 1388-1397.

93. Schwartz EA. Depolarization without calcium can release gamma-aminobutyric acid from a retinal neuron. Science (New York, NY) 1987; 238: 350-355.

94. Allen NJ, Káradóttir R, Attwell D. Reversal or reduction of glutamate and GABA transport in CNS pathology and therapy. Pflügers Archiv Eur J Physiol 2004; 449: 132-142.

95. Jin H, Wu H, Osterhaus G, Wei J, Davis K, Sha D et al. Demonstration of functional coupling between $\gamma$-aminobutyric acid (GABA) synthesis and vesicular GABA transport into synaptic vesicles. Proc Natl Acad Sci 2003; 100: 4293-4298.

96. Wojcik SM, Katsurabayashi S, Guillemin I, Friauf E, Rosenmund C, Brose N et al. A shared vesicular carrier allows synaptic corelease of GABA and glycine. Neuron 2006; 50 : 575-587.

97. Fish KN, Sweet RA, Lewis DA. Differential distribution of proteins regulating GABA synthesis and reuptake in axon boutons of subpopulations of cortical interneurons. Cerebral Cortex 2011.

98. Kanaani J, Kolibachuk J, Martinez H, Baekkeskov S. Two distinct mechanisms target GAD67 to vesicular pathways and presynaptic clusters. J Cell Biol 2010; 190: 911-925.

99. Kanaani J, Lissin D, Kash SF, Baekkeskov S. The hydrophilic isoform of glutamate decarboxylase, GAD67, is targeted to membranes and nerve terminals independent of dimerization with the hydrophobic membrane-anchored isoform, GAD65. J Biol Chem 1999; 274: 37200-37209.

100. Obata K, Fukuda T, Konishi S, Ji FY, Mitoma H, Kosaka T. Synaptic localization of the $67,000 \mathrm{~mol}$. wt isoform of glutamate decarboxylase and transmitter function of GABA in the mouse cerebellum lacking the 65000 mol. wt isoform. Neuroscience 1999; 93: 1475-1482.

101. Aroniadou-Anderjaska V, Qashu F, Braga MF. Mechanisms regulating GABAergic inhibitory transmission in the basolateral amygdala: implications for epilepsy and anxiety disorders. Amino Acids 2007; 32: 305-315.

102. Muller JF, Mascagni F, McDonald AJ. Postsynaptic targets of somatostatin-containing interneurons in the rat basolateral amygdala. J Comp Neurol 2007; 500: 513-529.

103. Rainnie DG, Mania I, Mascagni F, McDonald AJ. Physiological and morphological characterization of parvalbumin-containing interneurons of the rat basolateral amygdala. J Comp Neurol 2006; 498: 142-161.

104. Sosulina L, Graebenitz S, Pape H-C. GABAergic interneurons in the mouse lateral amygdala: a classification study. J Neurophysiol 2010; 104: 617-626.

105. Woodruff AR, Monyer H, Sah P. GABAergic excitation in the basolateral amygdala. J Neurosci 2006; 26: 11881-11887.

106. Katsumaru H, Kosaka T, Heizmann CW, Hama K. Immunocytochemical study of GABAergic neurons containing the calcium-binding protein parvalbumin in the rat hippocampus. Exp Brain Res 1988; 72: 347-362.

107. Fukuda T, Aika Y, Heizmann CW, Kosaka T, Dense GAB. Aergic input on somata of parvalbumin-immunoreactive GABAergic neurons in the hippocampus of the mouse. Neurosci Res 1996; 26: 181-194.

108. Smith Y, Pare JF, Pare D. Differential innervation of parvalbumin-immunoreactive interneurons of the basolateral amygdaloid complex by cortical and intrinsic inputs. J Comp Neurol 2000; 416: 496-508.

109. Prenosil GA, Schneider Gasser EM, Rudolph U, Keist R, Fritschy J-M, Vogt KE. Specific subtypes of GABAA receptors mediate phasic and tonic forms of inhibition in hippocampal pyramidal neurons. J Neurophysiol 2006; 96: 846-857.
110. McDonald AJ, Betette RL. Parvalbumin-containing neurons in the rat basolateral amygdala: morphology and co-localization of Calbindin-D(28k). Neuroscience 2001; 102 : 413-425.

111. Atack JR. Anxioselective compounds acting at the $\operatorname{GABA}(A)$ receptor benzodiazepine binding site. Curr Drug Targets CNS Neurol Disord 2003; 2: 213-232.

112. Rudolph $\mathrm{U}$, Mohler $\mathrm{H}$. Analysis of GABAA receptor function and dissection of the pharmacology of benzodiazepines and general anesthetics through mouse genetics. Annu Rev Pharmacol Toxicol 2004; 44: 475-498.

113. Pan B-X, Dong $Y$, Ito W, Yanagawa $Y$, Shigemoto R, Morozov A. Selective gating of glutamatergic inputs to excitatory neurons of amygdala by presynaptic GABAb receptor. Neuron 2009; 61: 917-929.

114. Yamada J, Saitow F, Satake SI, Kiyohara T, Konishi S. GABAB receptor-mediated presynaptic inhibition of glutamatergic and GABAergic transmission in the basolateral amygdala. Neuropharmacology 1999; 38: 1743-1753.

115. Pare $D$, Smith $Y$. The intercalated cell masses project to the central and medial nuclei of the amygdala in cats. Neuroscience 1993; 57: 1077-1090.

116. Royer $S$, Martina M, Paré $D$. An inhibitory interface gates impulse traffic between the input and output stations of the amygdala. J Neurosci 1999; 19: 10575-10583.

117. Amano T, Unal CT, Pare D. Synaptic correlates of fear extinction in the amygdala. Nat Neurosci 2010; 13: 489-494.

118. McDonald AJ, Mascagni F, Guo L. Projections of the medial and lateral prefrontal cortices to the amygdala: a Phaseolus vulgaris leucoagglutinin study in the rat. Neuroscience 1996; 71: 55-75.

119. Marowsky A, Yanagawa Y, Obata K, Vogt KEA. Specialized subclass of interneurons mediates dopaminergic facilitation of amygdala function. Neuron 2005; 48: 1025-1037.

120. Berretta S, Pantazopoulos H, Caldera M, Pantazopoulos P, Paré D. Infralimbic cortex activation increases $c$-fos expression in intercalated neurons of the amygdala Neuroscience 2005; 132: 943-953.

121. Quirk GJ, Likhtik E, Pelletier JG, Paré D. Stimulation of medial prefrontal cortex decreases the responsiveness of central amygdala output neurons. J Neurosci 2003; 23: 8800-8807.

122. Pape H-C, Pare D. Plastic synaptic networks of the amygdala for the acquisition expression, and extinction of conditioned fear. Physiol Rev 2010; 90: 419-463.

123. Schwarzer C, Sperk G. Hippocampal granule cells express glutamic acid decarboxylase67 after limbic seizures in the rat. Neuroscience 1995; 69: 705-709.

124. Esclapez M, Tillakaratne NJ, Tobin AJ, Houser CR. Comparative localization of mRNAs encoding two forms of glutamic acid decarboxylase with nonradioactive in situ hybridization methods. J Comp Neurol 1993; 331: 339-362.

125. Soghomonian JJ, Martin DL. Two isoforms of glutamate decarboxylase: why? Trends Pharmacol Sci 1998; 19: 500-505.

126. Feldblum S, Erlander MG, Tobin AJ. Different distributions of GAD65 and GAD67 mRNAs suggest that the two glutamate decarboxylases play distinctive functional roles. J Neurosci Res 1993; 34: 689-706.

127. Esclapez M, Houser CR. Up-regulation of GAD65 and GAD67 in remaining hippocampal GABA neurons in a model of temporal lobe epilepsy. J Comp Neurol 1999; 412: 488-505.

128. Ding R-g Asada H, Obata K. Changes in extracellular glutamate and GABA levels in the hippocampal $C A 3$ and $C A 1$ areas and the induction of glutamic acid decarboxylase- 67 in dentate granule cells of rats treated with kainic acid. Brain Res 1998; 800: 105-113.

129. Ramírez M, Gutiérrez R. Activity-dependent expression of GAD67 in the granule cells of the rat hippocampus. Brain Res 2001; 917: 139-146.

130. Gutiérrez R. Activity-dependent expression of simultaneous glutamatergic and GABAergic neurotransmission from the mossy fibers in vitro. J Neurophysiol 2002; 87: 2562-2570.

131. Gierdalski M, Jablonska B, Smith A, Skangiel-Kramska J, Kossut M. Deafferentation induced changes in GAD67 and GluR2 mRNA expression in mouse somatosensory cortex. Mol Brain Res 1999; 71: 111-119.

132. Benson DL, Huntsman MM, Jones EG. Activity-dependent changes in GAD and preprotachykinin mRNAs in visual cortex of adult monkeys. Cerebral Cortex 1994; 4: 40-51.
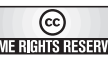

Translational Psychiatry is an open-access journal published by Nature Publishing Group. This work is licensed under the Creative Commons Attribution-NonCommercial-No Derivative Works 3.0 Unported License. To view a copy of this license, visit http://creativecommons.org/licenses/by-nc-nd/3.0/ 